\title{
Asymmetric cell division via DNA strand-specific epigenetic imprinting and segregation explains eukaryotic development
}

Amar JS Klar

From Epigenetics \& Chromatin: Interactions and processes

Boston, MA, USA. 11-13 March 2013

The asymmetric cell division is crucial during development and to produce self-renewing stem cells. A large body of work on Drosophila and C. elegans suggests that this process occurs by non-equivalent distribution of proteins and/or mRNA (intrinsic factors) to daughter cells, or by their differential exposure to cell extrinsic factors. In contrast, strictly based on template "Watson" versus "Crick" strand inherited from the parental cell, haploid fission yeast sister cells developmentally differ by inheriting sister chromatids that are differentiated by epigenetic means. Specifically, the double helical structure of DNA is the ultimate determinant of asymmetric cell division. To employ this kind of mechanism for cellular differentiation in diploid organisms, selective segregation must occur for partitioning epigenetically differentiated sister chromatids from both chomosome homologs to specific daughter cells, at a specific cell division, during multicelluar organism development. We previously proposed that Somatic Sister chromatid Imprinting and Selective chromatid Segregation (SSIS) model might explain development in eukaryotes, such as that of the body left-right axis laterality specification in mice and brain laterality in humans. However, for technical reasons, it is impossible to determine whether such a mechanism operates during embryonic development in higher organisms.

Recently we discovered the second example of DNA strand-specific imprinting mechanism in Schizosaccharomyces japonicus yeast (36\% GC content), whose DNA sequence is only about $30 \%$ similar compared to the wellstudied S. pombe (44\% GC). Therefore these highly diverged yeasts provide the first two examples in which the intrinsic chirality of double helical structure of DNA forms the

Developmental Genetics Section, Gene Regulation and Chromosome Biology Laboratory, National Institutes of Health, Frederick National Laboratory for Cancer Research, Frederick, MD, USA

\section{Biomed Central

๑ 2013 Klar; licensee BioMed Central Ltd. This is an Open Access article distributed under the terms of the Creative Commons Attribution License (http://creativecommons.org/licenses/by/2.0), which permits unrestricted use, distribution, and reproduction in any medium, provided the original work is properly cited. primary determinant of asymmetric cell division [1]. I will also discuss support for our model to explain body laterality development in mice [2]. Interestingly, another study also suggested that $C$. elegans neuronal asymmetry develops via the SSIS model [3].

Published: 8 April 2013

References

1. Yu C, Bonaduce MJ, Klar AJS: Defining the epigenetic mechanism of asymmetric cell division of Schizosaccharomyces japonicus yeast. Genetics 2013.

2. Sauer S, Klar AJS: Left-right symmetry breaking in mice by left-right dynein may occur via a biased chromatid segregation mechanism, without directly involving the Nodal gene. Front Oncol 2012, 2:166.

3. Nakano S, Stillman B, Horvitz HR: Replication-coupled chromatin assembly generates a neuronal bilateral asymmetry in C. elegans. Cell 2011, 147:1525-1536.

doi:10.1186/1756-8935-6-S1-P115

Cite this article as: Klar: Asymmetric cell division via DNA strandspecific epigenetic imprinting and segregation explains eukaryotic development. Epigentics \& Chromatin 2013 6(Suppl 1):P115.

Submit your next manuscript to BioMed Central and take full advantage of:

- Convenient online submission

- Thorough peer review

- No space constraints or color figure charges

- Immediate publication on acceptance

- Inclusion in PubMed, CAS, Scopus and Google Scholar

- Research which is freely available for redistribution 